Research Article

\title{
Gender preference among reproductive age group women in rural area
}

\author{
Vishal Samadhan Dhande*, Gadekar RD, Amol D. Shingare, Vijay K. Domple
}

Department of Community Medicine, Dr. Shankarrao Chavan Government Medical College, Nanded, Maharastra, India

Received: 18 May 2016

Accepted: 09 June 2016

\section{*Correspondence:}

Dr. Vishal Samadhan Dhande,

E-mail: drvishaldhande15@gmail.com

Copyright: () the author(s), publisher and licensee Medip Academy. This is an open-access article distributed under the terms of the Creative Commons Attribution Non-Commercial License, which permits unrestricted non-commercial use, distribution, and reproduction in any medium, provided the original work is properly cited.

\section{ABSTRACT}

Background: Skewed sex ratio is an issue of major concern and has long-term social and demographic consequences. In India, the preference for a son is very strong. The preference for a male child and discrimination against the female child are causing the rapid disappearance of female children in India. The main objective was to study the gender preference among rural married women in reproductive age group.

Methods: A community based cross sectional study on 220 rural married women of age group 15 to 49 years was carried out in Vishnupuri village of Nanded district in Maharashtra state, India. Information regarding gender preference, expected number of male or female children, awareness regarding PCPNDT act etc. was asked. A predesigned semi structured questionnaire was used for data collection.

Results: Out of 220 study subjects, majority of women i.e. 209 (95\%) said that they will prefer male child as first issue. $105(47.7 \%)$ women said that they expect children in 1 male: 1 female proportion, followed by 2 males: $1 \mathrm{female}$ proportion by $42(19.1 \%)$ women. $130(59.1 \%)$ have heard about PCPNDT act and not a single women tried for sex determination during her ANC period.

Conclusions: A strong preference to male child has been observed in females of reproductive age in rural area.

Keywords: Gender, PCPNDT act, Sex determination

\section{INTRODUCTION}

A sloka of Atharvaveda says "the birth of a girl, grant it elsewhere. Here, grant a son." Thousands of years later, this thing stands very true in modern times as well, when, despite the so called modernity, industrialization, literacy and equality, parents still pray this. ${ }^{1}$

The preference for sons or more number of sons than daughters has been documented in several countries in the world. ${ }^{2}$ Particularly in India, the preference for a son is very strong and pervasive and it has been frequently cited as one of the major obstacles in the way of reducing the national fertility level. ${ }^{3}$ The preference for a male child and discrimination against the female child are causing the rapid disappearance of female children in India.
With the prevailing son mania in the country it is not surprising that right from the first census of 1871, India has consistently shown an abnormal sex ratio (940 females for every 1000 males).But the most alarming and disturbing aspect of 2011 census is that the child sex ratio which is a measure of female/ male children below 6 years is even lower $(914 / 1000)$ and has fallen from 927 girls/1000 boys in 2001 and it is the lowest since $1947 .{ }^{4}$

India is having a patriarchal social framework where the preference for a son over a daughter is rooted in socioeconomic and cultural factors. The preference for male child has resulted in increased discrimination against girl child in this country. Not only they are devalued as human beings from the day they are born but also they are denied the right to be born if their families do not wish them to be born. ${ }^{4}$ female foeticide is one of the most serious forms of violence against women where 
female foetuses are selectively being aborted after prenatal sex determination. Over the past few decades this social menace has been spreading unchecked in this country.

\section{METHODS}

The present community based cross sectional study was carried out among rural married women in reproductive age group during September 2015 to November 2015. In Nanded district there are 16 talukas out of which one i.e. Nanded was selected randomly by lottery method. In Nanded taluka there are 89 villages, out of which one i.e. Vishnupuri was selected randomly. Total population of Vishnupuri is 6753 \& there are 1103 households. By systematic random sampling every $5^{\text {th }}$ house was selected. Only one woman from each house was selected randomly for study. Thus the sample size comes to be 220.

After obtaining informed consent, data was collected on predesigned and semi structured questionnaire. Information regarding sociodemographic factors like age, literacy status, occupation, type of family, socioeconomic status etc. was obtained from study population. Questions regarding gender related issues like number and proportion of expected children, gender preference in first issue, and awareness of decreasing female population in our community were asked and responses were noted. An attempt was made to know the awareness of PCPNDT act, provision of punishment under it and its source of information from study subjects. Data was analysed by using SPSS version 20.

\section{RESULTS}

In the present study maximum subjects i.e. $109(49.5 \%)$ were in the age group of 15 to 24 years followed by 105 $(47.7 \%)$ in 25 to 34 years age group and least i.e. 6 $(2.8 \%)$ in 35 to 45 years of age group. Mean age of respondent was 24.8 years (SD: 3.4). Regarding educational status, majority subjects i.e. $144(65.5 \%)$ were educated upto primary school followed by 27 $(12.3 \%)$ upto middle school, $22(10 \%)$ upto secondary school and only one $(0.5 \%)$ upto graduation (Table 1$)$.

Among 220 study subjects maximum i.e. 208 (94.5\%) were unemployed followed by $7(3.2 \%)$ unskilled worker, $4(1.8 \%)$ were semi-professionals and only one $(0.5 \%)$ was professional. More than half study subjects $(52.2 \%)$ were from joint family, 26.4\% were from three generation family and $21.4 \%$ were from nuclear family. According to modified BG Prasad Scale maximum study subjects i.e.101 (45.9\%) belonged to socioeconomic class IV, followed by $87(39.5 \%)$ class III and only one $(0.5 \%)$ from class I (Table 1).

Mean age at the time of marriage was found to be 18.3 years and mean age of first pregnancy was found to be 20.3 years.
Table 1: Sociodemographic factors of study subject.

\begin{tabular}{|c|c|c|}
\hline $\begin{array}{l}\text { Sociodemographic } \\
\text { factor }\end{array}$ & Frequency & Percentage \\
\hline $\begin{array}{l}\text { Age group } \\
15-24 \text { years } \\
25-34 \text { years } \\
35-45 \text { years }\end{array}$ & $\begin{array}{l}109 \\
105 \\
06\end{array}$ & $\begin{array}{l}49.5 \\
47.7 \\
2.8\end{array}$ \\
\hline $\begin{array}{l}\text { Educational Status } \\
\text { Illiterate } \\
\text { Primary } \\
\text { Middle } \\
\text { Secondary } \\
\text { Higher secondary } \\
\text { Graduate }\end{array}$ & $\begin{array}{l}19 \\
144 \\
27 \\
22 \\
7 \\
1\end{array}$ & $\begin{array}{l}8.6 \\
65.4 \\
12.3 \\
10 \\
3.2 \\
0.5\end{array}$ \\
\hline $\begin{array}{l}\text { Occupation } \\
\text { Professionals } \\
\text { Semi professionals } \\
\text { Skilled worker } \\
\text { Semi skilled worker } \\
\text { Unskilled worker } \\
\text { Unemployed }\end{array}$ & $\begin{array}{l}1 \\
4 \\
0 \\
0 \\
7 \\
208\end{array}$ & $\begin{array}{l}0.5 \\
1.8 \\
0 \\
0 \\
3.2 \\
94.5\end{array}$ \\
\hline $\begin{array}{l}\text { Type of family } \\
\text { Nuclear } \\
\text { Joint } \\
\text { Three generation }\end{array}$ & $\begin{array}{l}47 \\
115 \\
58\end{array}$ & $\begin{array}{l}21.4 \\
52.2 \\
26.4\end{array}$ \\
\hline $\begin{array}{l}\text { Socioeconomic Status } \\
\text { Class I } \\
\text { Class II } \\
\text { Class III } \\
\text { Class IV } \\
\text { Class V }\end{array}$ & $\begin{array}{l}1 \\
18 \\
87 \\
101 \\
13 \\
\end{array}$ & $\begin{array}{l}0.5 \\
8.2 \\
39.5 \\
45.9 \\
5.9\end{array}$ \\
\hline
\end{tabular}

Out of 220 study subjects, majority i.e.209 (95\%) said that they will prefer male child as first issue. $126(57.2 \%)$ study subjects expected two children in their family followed by 77 (35\%) expected 3 children and $16(7.3 \%)$ more than 3 children and there is only one $(0.5 \%)$ woman in the present study who expected one child in her family. (Table 2).

Regarding proportion of male to female children in the family, nearly half of study subjects $(47.7 \%)$ expected 1 male and 1 female child, followed by 2 males and 1female child by $42(19.1 \%)$ women and $27(12.3 \%)$ expected all male child in their family (Table 2 ).

$130(59.1 \%)$ women have heard about PCPNDT Act. Most common source of information of PCPNDT act was hospital staff $(49.1 \%)$ followed by television $(40.5 \%)$, and least common was news-paper (1.8\%). 202 (91.8\%) do not know about the punishment given if person found guilty in PCPNDT act. In the present study 202 (91.8\%) mothers had undergone USG examination during their ANC period and not a single woman tried for sex determination. Maximum (90\%) women were aware about decreasing number of female population in our community. The most common implication stated by them was "men won't find bride" (Table 2). 
Table 2: Response of study subjects regarding gender related issues.

\begin{tabular}{|c|c|c|}
\hline $\begin{array}{l}\text { Response to gender } \\
\text { related issues }\end{array}$ & Frequency & Percentage \\
\hline \multicolumn{3}{|c|}{ No. of children expected } \\
\hline 1 & 1 & 0.5 \\
\hline 2 & 126 & 57.2 \\
\hline 3 & 77 & 35 \\
\hline 4 & 15 & 6.8 \\
\hline$>4$ & 1 & 0.5 \\
\hline \multicolumn{3}{|c|}{ Proportion of expected children } \\
\hline $1 \mathrm{M}: 1 \mathrm{~F}$ & 105 & 47.7 \\
\hline $2 \mathrm{M}: 1 \mathrm{~F}$ & 42 & 19.1 \\
\hline $1 \mathrm{M}: 2 \mathrm{~F}$ & 30 & 13.6 \\
\hline $2 \mathrm{M}: 2 \mathrm{~F}$ & 7 & 3.2 \\
\hline All males & 27 & 12.3 \\
\hline All females & 9 & 4.1 \\
\hline \multicolumn{3}{|c|}{ Preference in first issue } \\
\hline Male & 209 & 95 \\
\hline Female & 11 & 5 \\
\hline \multicolumn{3}{|c|}{ Ever heard about PCPNDT Act } \\
\hline Yes & 130 & 59.1 \\
\hline No & 90 & 40.9 \\
\hline \multicolumn{3}{|c|}{ Source of information of PCPNDT act } \\
\hline Hospital Staff & 108 & 49.1 \\
\hline Television & 89 & 40.5 \\
\hline Relatives & 13 & 5.9 \\
\hline Family members & 2 & 0.9 \\
\hline Friends & 4 & 1.8 \\
\hline News Paper & 4 & 1.8 \\
\hline \multicolumn{3}{|c|}{$\begin{array}{l}\text { Provision of punishment if found guilty in PCPNDT } \\
\text { Act }\end{array}$} \\
\hline Yes & 18 & 8.2 \\
\hline No & 202 & 91.8 \\
\hline \multicolumn{3}{|c|}{ Female population decreasing in our community } \\
\hline Yes & 198 & 90 \\
\hline No & 22 & 10 \\
\hline
\end{tabular}

Keeping the family line alive was the main reason for son preference $(66.4 \%)$ followed by old age support for the parents (13.6\%) and girl will not stay with parents permanently (10.9\%) (Table 3 ).

Table 3: Reasons for preference of male child among study subjects.

\begin{tabular}{|lll|}
\hline Reason & Frequency & Percentage \\
\hline Keeping the family line alive & 146 & 66.4 \\
\hline $\begin{array}{l}\text { Old age support for the } \\
\text { parents }\end{array}$ & 30 & 13.6 \\
\hline $\begin{array}{l}\text { Girl will not stay with } \\
\text { parents permanently }\end{array}$ & 24 & 10.9 \\
\hline $\begin{array}{l}\text { Boy helps to father in his } \\
\text { work }\end{array}$ & 20 & 9.1 \\
\hline
\end{tabular}

There is no statistically significant association between sociodemographic factors like type of family, socioeconomic status and educational status with gender preference of first issue (Table 4).

Table 4: Association between sociodemographic factors and gender preference of first issue.

\begin{tabular}{|llll|}
\hline $\begin{array}{l}\text { Socio-demographic } \\
\text { factors }\end{array}$ & $\begin{array}{l}\text { Gender preference of } \\
\text { first issue } \\
\text { Male child }\end{array}$ & $\begin{array}{c}\text { Female child } \\
\text { square }\end{array}$ \\
\hline $\begin{array}{l}\text { Type of family } \\
\text { Nuclear family }\end{array}$ & 45 & 2 & $\mathrm{X}^{2}=0.597$, \\
Joint family & 110 & 5 & $\mathrm{p}=0.7419$, \\
Three generation & 54 & 4 & $\mathrm{~d} . \mathrm{f}=2$ \\
\hline SES & & & \\
Class 1 & 1 & 0 & $\mathrm{X}^{2}=6.7458$, \\
Class 2 & 15 & 3 & $\mathrm{p}=0.1499$, \\
Class 3 & 85 & 2 & $\mathrm{~d} . \mathrm{f}=4$ \\
Class 4 & 96 & 5 & \\
Class 5 & 12 & 1 & \\
\hline $\begin{array}{l}\text { Educational } \\
\text { status }\end{array}$ & 19 & 0 & $\mathrm{X}^{2}=6.1111$, \\
Illiterate & 133 & 11 & $\mathrm{p}=0.256$, \\
Primary & 27 & 0 & $\mathrm{~d} . \mathrm{f}=5$ \\
Middle & 22 & 0 & \\
Secondary & 7 & 0 & \\
Higher secondary & 1 & 0 & \\
Diploma & & & \\
\hline
\end{tabular}

\section{DISCUSSION}

Preference for male child over the female has been a part of Indian culture and mindset since time immemorial. In Indian culture, the male members, especially the son plays an important role during family rituals like cremation of parents. Son is considered to be one, who will carry forward the family and the property. He is been supposed to earn for whole family and safeguard it from evil forces in the community. He is considered as an old age support for the parents, since females leave the parents house after marriage and become part of some other family. ${ }^{8}$

The study conducted by Chavada $\mathrm{M}$ et al, Observed that son preference in rural areas $(94.30 \%)$ is more than urban areas and difference was statistically significant. ${ }^{5}$ Present study is conducted in rural area and the gender preference for son observed to be very high $(95 \%)$.

When asked about number of children they desire in the family, majority $(57.3 \%)$ felt two is the ideal number of children. This is similar to the observations made by Puri et al and Pavithra et al in their studies. ${ }^{6,7}$

In the present study, it was observed that the most preferred sex combination was one male and one female child. It was followed by two male children in the family. These findings are similar to study of Vidyadhar BB et al in Central India. ${ }^{8}$ 
However in spite of tremendous efforts by government to implement legal rules and regulations regarding female feticide and prenatal sex determination only $59.1 \%$ pregnant women in our study had ever heard of PCPNDT Act. Similar to study by Pavithra et al in Bengaluru where 59\% women had never heard about PCPNDT act. The awareness regarding the act was higher in our study compared to Srivastav et al in UP where only $32 \%$ were aware of PCPNDT act. ${ }^{9}$

In our study the knowledge about punishment given if person find guilty in PCPNDT act was minimum (8.2\%), in similar studies from Chandigarh and Bagaluru only 16 $\%$ had knowledge about punishment given under PCPNDT act. ${ }^{6,7}$

Age at marriage and age at first conception are two direct factors that influence fertility. The mean age at marriage among women in the present study (18.29 years) is similar to study by Mohammad Asghar et al in Manipur. $^{10}$

Age at first conception is more important than the age at marriage in determining the fertility. In the present study, mean age at marriage and mean age at first conception have difference of 2.02 years.

$90 \%$ women are aware about decreasing number of females in our population. After asking the future problem due to decreasing female in community, common implications stated by them was "men won't find bride" Similar implications were reported by Vadera et al and Walia A et al. ${ }^{11,12}$

\section{CONCLUSION}

The present study has shown that there is a strong preference for male child in the community. Keeping the family line alive is the most common reason for preference of male child. Majority of women expect children in 1 male: 1 female proportion. Majority of women heard about PCPNDT Act and the source of information was hospital staff. Not a single woman tried for sex determination during her ANC period.

\section{Funding: No funding sources}

Conflict of interest: None declared

Ethical approval: The study was approved by the Institutional Ethics Committee

\section{REFERENCES}

1. Audio-Visual Review. Born female, Produced by UNICEF Regional Office for South Central Asia. Govt. of India. Directed by Nilanjana Mukherjee 1985. Indian J Social Work. 1991;52:115-7.
2. Cleland JG, Verrall J, Vaessan M. 1983. Preference for the sex of children and their influences on Reproductive Behavior World Fertility Survey: Comparative Studies, No.27, International Statistical Institute, Voorburg, Netherlands.

3. Rajarethanm T, Desphande RV. Gender Preference an India's Missing Girls: Evidence from same selected states of India; Population Association of America 1994, Boston, USA.

4. Office of the Registrar General and Census Commissioner, India. Census of India, Govt of India; 2011. Available from: http://www. censusindia.gov.in/ [Last accessed on 2015 Dec.2]

5. Chavada M, Bhagyalaxmi A. Effect of sociocultural factors on the preference for the sex of children by women in Ahmadabad district. Health and population Perspectives and Issues. 2009;32(4):184-9.

6. Puri S, Bhatia V, Swami HM. Gender preference and awareness regarding sex determination among married women in slums of Chandigarh. Indian $\mathbf{J}$ Community Med. 2007;1:60-2.

7. Pavithra MB, Dhanpal S, Lokanath H. A study of gender preference, knowledge and attitude regarding prenatal diagnostic techniques act among pregnant women in an urban slum of Bengaluru. Int $\mathrm{J}$ Community Med Public Health. 2015;2:282-7.

8. Vidyadhar BB, Giri PA. Sex combination of living children at the times of sterilization among rural women of central India. International Journal of Basic and Applied Medical Sciences. 2012;2(3):637.

9. Shrivastava S, Kariwal P, Kapilasrami MC. A community based study on awareness and perception on gender discrimination and sex preference among married women (in reproductive age group) in a rural population of district Bareilly, Uttar Pradesh. Nat J Commun Med. 2011;2:273-6.

10. Mohammad A, Murry B, Saraswathy KN. Fertility Behaviour and Effect of Son Preference among the Muslims of Manipur, India. Journal of Anthropology. 2014 available at http://dx.doi.org/10.1155/2014/108236.

11. Vadera BN, Joshi UK, Unadakat S, Yadav BS, Yadav S. Study on Knowledge, attitude and practices regarding gender preference and female feticide among pregnant women. Indian $\mathbf{J}$ Community Med. 2007;32:300-1.

12. Walia A. Female feticide in Punjab: Exploring the socio-economic and cultural dimensions. J Soc Issues. 2005;10(1).

Cite this article as: Dhande VS, Gadekar RD, Shingare AD, Domple VK. Gender preference among reproductive age group women in rural area. Int $\mathbf{J}$ Community Med Public Health 2016;3:1862-5. 